\title{
PARADOXALITY OF CONSTITUTIONALIZATION TO RIGHT TO HEALTH
}

\author{
Sandra Regina Martini \\ University of Vale do Rio dos Sinos (UNISINOS)
}

The health constitutionalization is directly related to the democratization process in Latin America starting from the 80s. In the following decades we lived, as stated by Bobbio, "an era of rights"1, where most of the social demands became social rights. However, we still lack the right to be entitled to such effected rights.

This article has the scope to discuss the limits and possibilities of the right to health in a highly complex and paradoxical society. We never had so many rights, and that is because these rights are not made effective; there is an exclusion in the same proportion as the assertiveness of the same rights.

In other words, when the right to health was not guaranteed, we were not excluded from this right. Today, this right is guaranteed to us all, however, this service is not provided (not even minimally), we are more excluded than ever. We also noticed we have "ideas" of rights, as much as ideas about democracy, but when these ideas do not work, as stated by Luhmann, we have to explain why they do not work.

This aspect can be translated as paradoxical due to the existence of many possibilities and, at the same time, limits. This will be one of the aspects that we will reflect on. More than that, we would also like to demonstrate that, not rarely, the right to health appears much more as a value and/or an idea than as a right.

These reflections are only possible in a functionally differentiated society, in which the difference between the most diverse social systems allows the social evolution, that is, permits claiming democracy exactly because we have democracy. The democratic deficit only exists, paradoxically, when we have democracy. On the other hand,

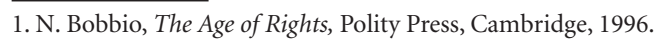


democracy can be represented by the autonomy of the Constitutions, which represents the structural coupling between the Politics and the Law system. It is through this autonomy that the Constitution constantly brings together the Politics System and the Law System, showing that it has an important role in the law change. However, if this change is only made within the limits of the law itself, the same applies for the political system, as well as to all other social systems.

The terms "reaction" and "autonomy" show the limits and possibilities of each system, and rather highlight the structural problems of the system itself. We continue understanding, for example -and paradoxically need-, the law of the nation-state assumption, in that our main reference to the Law a clear geographical boundaries, a sense of sovereignty. But when we take a look at the system of politics or economics, we see that its assumptions are much more linked to the idea of global society. These restrictions may also become possible. This is the ambivalence game of living in a different society functionally, in which we also have as a possibility the rapprochement between the social systems through cognitive opening.

\section{The limits and possibilities of Constitutions}

The limits and possibilities can be very timely to analyze the evolution of modern society, as we always operate exceeding limits and then create possibilities ${ }^{2}$. Thus, given the possibilities, at the same time we create new limits, which once again can introduce and, in fact, present possibilities. This is the current functioning of social systems in which the Constitution is presented as relevant to both sides of the limits/possibility form. The fact is that we have talked a lot about this, but little did we use it as an analytical tool. The purpose of this article is also exploring this form of analysis because it allows us, for instance, to constantly unravel the paradoxes of universal inclusion. Trying to understand, as Eligio Resta, that the limit may also have another meaning, when dealing with the question of identity:

The limit, they said, defines and individuates; but at the same is also a source. It comes in the form of oxymoron, an individuation that does not forget its origin,

2. N. Luhmann, Sociologia do Direito I, Tempo Brasileiro, Rio de Janeiro, 1983. 
in which individuation is confused. Among the new identity and its difference the bond that separates is the same as links: what defines them is also what brings them together ${ }^{3}$.

We use this concept to treat the Constitution as a modern identity, playing often a dual role play, or, as Resta stated, "plays with the complicity of their opposites."4 Other times, it can be identified within the limit, a source, but the ambivalence has been always present: the same bond which unites can separate. For example, we can speak of the role that the Paraguayan Constitution "played" in 2013, when there was the "political coup" in Paraguay, that is, a Constitution designed to guarantee democracy can guarantee (and secured) its opposite, because we cannot say the impeachment process was democratic, since in 18 hours the whole process was fulfilled. This makes us think of which constitutional identity prevails, the democratic one or the one of the old "political caste". We do not deepen the discussion of this example, but it shows us how the game limit/possibility operates. For Emilio Camacho:

A parliamentary coup which happened in Paraguay is a blow to democracy in Latin American and is an attack against the principles of universal democracy, a direct threat to the region starred by more conservative and antidemocratic sectors of society, which may be extend to other countries with weak institutions ${ }^{5}$.

Again, we see that this imposed limitation can turn into opportunities, because something that happens in a particular state impacts on the others. This is what happened in this episode, which unveiled the double game that the Constitution itself can represent. We believe that this coup demarcates, in Latin America, the weaknesses of our democracies and reveals the role of constitutions as self-administered.

So, to talk about the current character of the constitutionalization of rights is also to talking about paradoxicality surrounding this era of "universal constitutionalization"6. We need to identify how we will all be -whether we- included universally, if this is indeed possible, and what are the limitations that prevent this advance or if we are dealing with something much more evaluative, morally correct, but without the concrete

3. E. Resta, Percursos da Identidade. Uma Abordagem Jusfilosófica, Unijuí, Ijuí, 2014, p. 102.

4. Ibid.

5. E. Camacho, Golpe parlamentario en Paraguay: una aproximación jurídica, Editorial Arandurã, Paraguay, 2012, p. 27.

6. S.R.M. Vial, "Saúde e determinantes sociais: uma situação paradoxal”, in: Revista Comparazione e Diritto Civile, v. 1, 2010, p. 16. 
possibility of realization. Constitutionalizing rights is not enough! An organizational program in which these rights leave the symbolic level to the actual plan is needed. We need to deal with rights and not values, in the case of social system.

The reflections on another model of law were always present during jusphilosophical debate. Kant, for example, tells us of a cosmopolitan law, where the rational idea of a "perpetual peaceful community" is not effective, more than that, he says that the possibility of living together in harmony cannot be seen as a philanthropic principle, but as a legal principle since "the nature closed all people together"

$\mathrm{Kant}^{8}$ points out the limits of living in the same soil, originally in communion, not the same situation in the legal perspective of ownership of the same land, but think of a relationship of each with all, without which, as pointed out by Kant, the foreigner may be seen as an enemy. Thus, the law could allow an association with all the people in accordance with universal laws (which, at present, are not lacking), and this law can be called cosmopolitan. The sea, wich could be another limit for this law, is also present and, at the same time, there are possibilities through modern mechanisms of navigation.

These current reflections of Kant are important from their own assumption of peace being the only state in which the "mine" and the "yours" are guaranteed by the law in which the "neighbors" may be joined by a constitution in which power is in the law and not in men. This Constitution should be implemented in a gradual way in accordance with firm and strong principles, in a continuous process of coming to life in eternal peace. The limits for this peace are placed, as well as its possibilities.

\section{The contribution of Systemic Theory uneasiness for the analysis of Sociology of Constitutions}

In order to investigate how the Theory of Social Systems ${ }^{9}$ can contribute to the analysis of this fact, it is necessary to return to the inquiries of Niklas Luhmann on the very Sociology and then see if we can actually speak of a sociology of the Constitutions or if we are talking about a sociological, and systemic analysis of Constitutions. In particular, we must consider the following questions, highlighted by Luhmann: "What is the case?" and "What is lies behind it?" 10 These questions answered from the

7. I. Kant, Doutrina do Direito, 3 ed. Ícone, São Paulo, 2005, p. 38.

8. See I. Kant, Doutrina do Direito, 3 ed. Ícone, São Paulo, 2005, p. 38.

9. See N. Luhmann, R. De Giorgi, Teoria della società, 8 ed. Franco Angeli, Milano, 1996, p. 40.

10. See N. Luhmann, Introducción a la teoría de sistemas, Universidad Iberoamericana, México, 1996, p. 341. 
perspective of the Theory of Social Systems, lead us not to answers but to more questions. Initially, it is important to think that the one that observes indicates, selects, and establishes differences ${ }^{11}$. In this complex process you cannot think of the separation subject-object; i.e., to handle the case and see what is behind it is to see what is behind the observer which observes and, more than that, "to observe means only: distinguish and indicate" 12 .

To the extent that this theory searches to uncover paradoxes and not simply "identify them as a social problem" or, perhaps even worse, "solve social problems", causes doubts and unrests. Here, we may ask: what it is the function of science? Which is the function of sociology? And on this, Luhmann highlights:

As science, Sociology can only stablish itself over a communication base, referring to its contribution only to internal description about this system and without taking any external position in this system because it would mean not being able to express it $^{13}$.

From this statement, we see that sociology is also being established. Thus, the idea of Sociology of the Constitution is born with the thought of Alberto Febbrajo and Giancarlo Corsi, who note that the constitutions have been used in modern society, in theory, to allow the study of the "relationship" between Law and Politics.

This is a very complex relationship, in that the politics, in today's society, presents itself as a world system, while the law remains local/national. In other words, the politics is targeted, but the society is worldwide, although we continue with the territorial limitations. We don't have, for example, a world constitution.

Theories or sciences, in general, produce different effects on scholars. Sociology, in particular, traditionally parts of, as stated by Luhmann, the mentioned two issues (discussed in his last class of the subject in Bielefeld). The first is: what is the case? Then the question is: what is lies behind it? These questions led to reflections on unity of difference, that is, on a paradox ${ }^{14}$. So, sociology describes the society as a system that describes itself. However, after completing the lesson, Luhmann notes: "We would have a society

11. N. Luhmann, ¿Cómo es posible el orden social?, [Pedro Morandé Court (transl.)], Editorial Herder, México, 2009, p. 29. 12. See N. Luhmann, R. De Giorgi, Teoria della società, 8 ed., Franco Angeli, Milão, 1996, p. 23. "Osservare significa semplicemente (e cosí utilizzeremo in seguito sempre il concetto): distinguere e indicare".

13. See N. Luhmann, Introducción a la teoría de sistemas, Universidad Iberoamericana, México, 1996, p. 341.

14. Ibid., p. 361. 
that, with sociology support, would describe itself. And what is behind it? Absolutely nothing ${ }^{15}$.

The Niklas Luhmann's Theory of Social Systems "revolutionizes" the sociological tradition, and has an uneasy effect (as of today) ${ }^{16}$ : this theory is presented with several advantages, because, in addition to causing uneasiness to any researcher, it also, and at the same time, presents itself as a challenge to the analysis of social complexity, since it does not accept the traditional theories in its entirety, but uses them to show the internal weaknesses of the theory itself $\mathrm{f}^{17}$. In addition, all the construction of the theory base is transdisciplinary and constructivist: this, on the one hand, facilitates the process of understanding the current society; on the other, it does not "admit" linear analysis, that is, each analysis may be different from what was formulated ${ }^{18}$.

Continually, we repeat the Luhmann's questions, especially the question "What right has the right to say what is right?" And how this law reacts to autonomy. These questions have been subject of reflection for sociologists, lawyers, philosophers, among others: the answers always generate new questions. In the specific case of sociology, this question "disassembles and assembles" the traditional theories of sociology itself. Until the 60s sociology, with rare exceptions, did not in its "object" of study "say and decide the law." Especially in Latin America, our "object" of study and concern was in other fields. The problem of the "right to say what is right" entered the world of sociology in Brazil, only after this period through the various movements of criticism of the law, and the same was true in other Mercosur countries.

To observe the role that constitutions are having in modern society, it is considered important to use the tools of the Theory of Social Systems, which identify the possibility of a specific line of research. Reaffirming the Systemic Theory, Febbrajo and Corsi ${ }^{19}$ show that the Constitution was invented to allow the "relationship" between Law and Politics in the context of modernity. The limitation of politics and law is given in the Constitution, and the symbolism of the Constitution is also questioned by Febbrajo and Corsi, creating often a disorder in the law, which is not negative or positive, but may have a solution or even reveal the "fragmentation" of the law in force, namely the Law (un)ordered can find organizational solutions. The Constitution follows as identity of a

\footnotetext{
15. Ibid., p. 369.

16. See N. Luhmann, ¿Cómo es posible el orden social?, Editorial Herder, México, 2009, p. 18.

17. See C. F. Campilongo, Interpretação do Direito e Movimentos Sociais, Elsevier, Rio de Janeiro, 2012, p. 42.

18. O. Dallera, La sociedad como Sistema de Comunicación: La teoría sociológica de Niklas Luhmann en 30 lecciones, Biblos, Buenos Aires, 2012, p. 131.

19. A. Febbrajo; G. Corsi, Sociology of Constitutions: AParadoxical Perspectives. Studies in the Sociology of Law, Routledge, 2016.
} 
State; changing its essence is very difficult and complex. So, we are continually changing legal rules, and limiting these changes is the Constitution itself. Febbrajo adds: warning about the importance also of the economic system, that is, in addition to considering the Constitution as a structural coupling between law and politics, also adds the economic system.

Understanding that the Constitution is an evolutionary acquisition ${ }^{20}$ that serves as a starting point for reflection of the Constitution beyond the numbers, Luhmann conceives the constitution as "a reaction to the differentiation between politics and law, and said further emphasis to the total separation of the two system functions and the consequent need for reconnection between them" ${ }^{21}$. For Luhmann, law and politics are "free" to ignore the scientific opinions concerning them, and it is this freedom of Sociology and of the Constitutions it may develop.

Sociology, in a general and traditional way, has not reflected on the subject. Though it should not take care of the improbabilities of social structures, little is dedicated to the specific theme. However, today it has attracted the attention of sociologists, especially the "divine" character that the Constitutions represent.

At the same time, the constitutions play an important role. In Europe, although people do not "speak" of the Constitution, everyone knows of its existence, and it is known that it serves as a limit (as stated by Febbrajo ${ }^{22}$ ); in Latin America, the situation is more complex: the Constitution remains "constituted of values", that is, the result of processes lived here, where, unlike the European countries, the constitutions were and are a pass mark of authoritarian regimes for democratic regimes (even though we may question the level of democracy, or how democratic is democracy, which is possible only because, in a way, there is a level, however minimal, of democracy). Therefore, the Latin American continent is in urgent of a deep sociological reflection on this issue, since, traditionally, when studying the subject, the focus has been on the function, legitimacy, the constitution foundation or, translated into practical terms, in many cases, followed by treating the "sacredness" of the Constitution. However, we believe that a Sociology of Constitutions could deepen, especially the place of organizations and social framework for the enforcement of the Constitution. In Brazil, there are many studies on the subject of the Constitution, largely carried out in the framework of the law; however, it seems urgent to review the issue with the focus of sociology.

20. G. Schwartz; J. Pribàn; L. S. Rocha, Sociologia sistêmico autopoiética das constituições, Livraria do Advogado, Porto Alegre, 2015.

21. N. Luhmann, Sociologia del rischio, Editore Bruno Mondadori, Milano, 1996, p. 4.

22. See A. Febbrajo; G. Corsi, Sociology of Constitution. 
As stated by Corsi, it is appropriate to see the specificity of sociology in the fact that, unlike the theories of law or political science, has the task of giving operational guidance to the courts or to political action. Ultimately, the theory of law is still only part of the legal system and there make sense, as well as political science is only ever part of the political system. It is therefore a problem of differentiation of the society, which involves distinct functions for the different subsystems and therefore also problems, different theoretical concepts and constructions. In terms of research, we can thus emphasize the interdisciplinary or "transdisciplinary", which presupposes the diversity of perspectives and the study of the constitution is a pretty clear case of research involving different perspectives $^{23}$.

A sociology of the Constitution should neither be ideological, nor operate in the same manner as would Law and Political Science. A Sociology of the Constitution should be aware that the Constitution is a self-legitimating instrument, it speaks of itself and the possibility of its own demise. In this new area of knowledge, the Constitution should be "unveiled" of its values, ideals and sacredness. Therefore, a fundamental question is presented: how to do this? How do we not repeat the initial questions posed by sociology and get to the answer given by Luhmann when he says that there is nothing behind it.

As noted by Luhmann, the Constitution should provide boundaries to law and policy and, therefore, both law and policy may give grounds for the lack of fundamentals. In other words, the Constitution has a highly paradoxical nature: as it limits law and policy, it also provides for the power to halt itself. This is the paradox and, as we understand, a paradox is created when the conditions of its possibility are also the conditions of impossibility.

\section{Health: from value to constitutional embodiment}

When health becomes constitutionalized, does it reinforce the idea of value? Or can you think of a it in terms of right, of an entitlement? Is it possible to transition from value to a right? What is the limit of this right? What links with the future can this right-value or value-right mean? Is it possible to realize a value?

23. G. Corsi, “On Paradoxes in Constitutions” in A. Febbrajo, G. Corsi, Sociology of Constitution, pp. 11-29. 
Health has been discussed and defined according to several parameters, in the most varied historical periods. Although the modern definition encompasses the integrality of life in society, we see that this concept is still presented as a value, although one of the most stated and visible value in the symbolic landscape of modern society. It is not strange to be so, as any other value assumes that individuals are able to enjoy the physical and mental well-being; without health, other values become unenforceable. The illness, especially if severe, attacks the possibility of freedom or equality of an individual and can even put in discussion the very dignity (or the very conditions of dignity in life).

With the evolution of modern society, we observed that some values may become law or, perhaps, this is the latent expectation in Latin America. And, at this point, new complexities arise: if health is a fundamental value and, as such, should be guaranteed to all to the point that it appears in most modern constitutions, we must have programs and structures that allow for the transposition of a value into a right. Namely, once recognized that health is an inalienable right, conditions must be established for guaranteeing this right. The problem is how and where to set the criteria for the health and right systems to operate, or rather, how this right can be decided on the health system structure. In this situation, we must also consider the Political system, which, from their point of view, sees the affirmation, also constitutional, of fundamental rights as an "undisputed" point, without worrying about the consequences of these rights. Health for all, as well as work for all, and equal opportunities are classic social struggles. The problem (and the solution) is exactly this "all” because "all” (as in everyone) is distinguished from "none" (i.e. not one), since we are facing the risk that no one or only a few can truly enjoy these rights. Nevertheless, politics, if it is democratic, cannot be decided without thinking of all, at any cost.

Speaking of health as a right, or even, a value for a right also means thinking seriously about the issue of social exclusion. In contemporary society, one should be aware that, particularly in politics, where there is a lot of inclusion, this often happens through topic exclusion (generalization leads to marginalization?). Thus, health remains "conceived, organized and planned" as a value. Today, we talk about the diseases of civilization, epidemics that spread unchecked, new diseases (e.g. violence is now considered a health problem), environmental disasters, among others. We can observe that the guarantee of quality in health (or social health systems) undergoes a widespread process of inclusion.

The role of a "sociology of the Constitutions" could be, in case of health, to present the sociocultural conditions that allow this universal inclusion (if they allow) and the 
obstacles to the passage of health as a value for health as a right. One should ask, in other words, how you can enable and support the cure of diseases by placing as a reference point the value of health. Just if you take seriously this value, the social reality is likely to be questioned from the point of view of the disease, and this may have an impact not only on medicine (for which this is quite normal and obvious), but also on other subsystems of society ${ }^{24}$.

To understand what the paradoxicality of the value or the right to health entails, it is necessary to analyze what are the implications of the prevention and cure of a disease. Here we enter into another field: the social and ethical dimensions of the disease. Without going into detail on these dimensions, it is relevant to name them because they reflect the complexity of what the topic generates. More than that, parting from the perspective of the Sociology of Constitutions, we can reflect on whether, by assuming the social and ethical dimensions of a disease, we are not, in fact, distancing ourselves from the realization of minimum health conditions. How will social systems operate with such a complex value as health?

Hence, we see that the perspectives of various social systems are different: just think of the religion(s) system(s) perspective(s), for example. If we think about the educational system, as well, and its relationship with health, one might ask "how can information transform value into right"?

\section{Final considerations}

El concepto de inclusión significa la incorporación de la población global a las prestaciones de los distintos sistemas funcionales de la sociedad $^{25}$.

The constitutionalization of the right to health generates an inclusion and, at the same time, an exclusion, that is, we have a right that is not effective; hence, access to the right to have rights is denied to much of the global population. This can be seen through the global health emergencies, in which much of the population (particularly the most excluded) shall be considered for their impact on global contamination risks.

24. Ibid.

25. N. Luhmann, Teoría Politica en el Estado de Bienestar, Alianza Universidad, Madrid, 2007, p. 48. 
Within the health law analysis, we should note that the unrest caused by systemic theory appears as a challenge to the analysis of social complexity. The transdisciplinary and constructivist foundations of this theory are appropriate to the understanding of the right to health in today's society, with a view that no longer admits linear analysis, given the complexity inserted into the right to health.

The right to health, understood as complete physical and mental well-being, has been recommended by international agencies for decades, but it seems that it only becomes relevant when we have situations that threaten the populations that are at the heart of modernity. Not infrequently, the measures taken are more "police"-oriented rather than aiming for effective prevention. It seems that we have to have health emergencies in order for measures of prevention and health protection as the law to take effect. This no doubt is what Luhmann describes as paradox of inclusion. We live in an artificially universal inclusion, as this inclusion constantly generates exclusions. So it is time to take back the old questions: must we even include to exclude? Is democracy actually democratic? Even when will, in Latin America, the right to health be a mere value? Therefore, it is important to strengthen the role that a sociological analysis of the constitutions has to unveil the sociocultural conditions that hinder the effectiveness of rights, such that in the Latin American context, are seen as more values than as enforceable rights.

On the question of health, it should be noted that it is considered as value and demands the right to understand the idea of ambivalence and paradoxical contained in health. Please observe the relationship between prevention and cure of disease, and this brings us back to the social and ethical course of the disease. 